Seminars, Conferences, Addresses

\title{
A Report on the International Seminar on Religions and Contemporary Development
}

\author{
25-28 Rabi al Awwal 1413 / 23-26 September 1992 \\ Ambarrukmo Palace Hotel, Jogjakarta, Java, Indenesia
}

The International Seminar on Religions and Contemporary Development was sponsored by the Sunan Kalijaga State Institute for Islamic Studies, located in Jogjakarta, Java, Indonesia. This seminar was a major event for scholars of Islamic studies in Indonesia, as it was opened by the Indonesian Minister of Religious Affairs, Munawir Sjadzili. The conference secretary, Rifa' $i$ Abduh, and the conference chair, Burhanuddin Daya, organized the conference in order to address the issues of religious fundamentalism, and Islam and development.

Peter Clarke (King's College, University of London, UK) spoke on "Contemporary Problems of Religion in Europe." He stated that technology has become a religion, for many Europeans actually believe in it. In the same way that Christians believe that God can do anything and everything, secularists believe that technology can do anything and everything. Bert Breiner (Selly Oak College, Birmingham, UK), speaking on the same issue, said that religious groups in westem Europe have tended to accept the dominant epistemology of scientific empirical objectivity:

The major problem of religion in contemporary Europe is the question of revelation. Unless religious thinkers can evolve an understanding of religious truth in general, and of religion in par- 
ticular, which is independent of this particular epistemological principle, it will have little to offer the development of contemporary European civilization.

Martin van Bruinessen (University of Leiden, the Netherlands) addressed "Muslim Fundamentalism: Can It Be Understood or Should It Be Explained Away?" He thinks that it can be understood and notes that violent action in the name of Islam is not a direct result of radical religious doctrines, but a consequence of certain social factors that may predispose some people to militancy. How a person becomes a fundamentalist can be explained by the religious climate in his/her family, the accessibility of certain literature, and the frequency of contact with recruiting activists.

Piniti Ratanakul (Mahidol University, Bangkok, Thailand) wrote a paper on "Religion and Poverty: The Response of Thai Buddhism to the Cry for Justice." He was unable to attend the conference, so the paper was read by Imtiaz Yusuf. He noted the response of some Thai monks to contemporary social, economic, and political developments in Thailand. These "development monks" participate in social work at the village level, which includes road construction, the digging of wells, and vocational training. The monks provide the leadership, while the villagers provide the resources. Such monk-initiated projects help to eradicate poverty by eradicating its sources (water scarcity, salty soil, exploitation, indebtedness, alcoholism, and gambling).

Nurcholish Madjid (State Institute for Islamic Studies, Jogjakarta, Indonesia) addressed the issue of "Islamic $D a$ wah in Indonesia: The Challenge of Post-Colonialism and Social Change in a Plural Society." An important point he emphasized was that Muslim missionaries have had a hard time meeting the challenges of industrialization in Indonesia. The youth are attracted to Muslim activists who promote antisocial, assertive, and uncompromising attitudes, and are not being attracted by the Muslim activists who promote socially constructive, pluralistic, and cooperative attitudes. Islamic $d a$ wah efforts have found it difficult to face many challenges. In particular, Muslim activists have made the claim that Islam promotes pluralism, but have yet to put this claim into political and social reality and to integrate it into the themes of the Islamic movement.

Mukti Ali (State Institute for Islamic Studies, Jogjakarta, Indonesia) spoke on "Religion, Morality, and Contemporary Development." His talk emphasized the fact that disunity exists in the world due to many developments. Unity, however, cannot be achieved unless the following is accomplished: the establishment of an organization that unites all the world's religions under one body, the Islamization of society, polity, and economy, and the development of the moral disciplines.

Abu el Wafa el Taftazany, former rector of the University of Cairo, Egypt, presented a paper entitled "The Role of Sufism in Modern So- 
ciety." He argued that contemporary world developments have led to mental instability. Religion can address this instability by bringing peace of mind, which is the prerequisite for mental stability. Sufism can bring about peace of mind by removing the extremes of grief and rejoicing. The true path to psychological health is Islam; non-Islam (atheism, Marxism, existentialism) leads to psychological problems.

Omar Altalib (University of Chicago, Illinois, USA) spoke on "Religious Morality in America." He argued that religious morality has been decreasing among Christians in America, while secular morality has been increasing. This is due to many sociological factors, including the following: many churches accept racism; arrogance among many Americans has made them comfortable with the idea of being accountable only to one's self rather than to God; several public scandals involving clergy have occurred; and there are many strong alternatives to the church where people can go if their conscience bothers them (such as psychologists, political parties, Boy Scouts and Girl Scouts).

The conference was successful in bringing together a group of scholars from around the world to address issues that are serious within a Muslim context and in increasing Muslim understanding. The organizers of the conference did a wonderful job of having just the right amount of presentations per day, with enough time for questions and answers. In order to improve similar seminars in the future, I would suggest having all papers available in both Indonesian and English. This review covers only those paper written in English, even though the ones in Indonesian were equally enlightening. Copies of the papers may be obtained by writing to: Muslim Social Scientists Group, 6055 South Drexel Avenue, Chicago, IL 60637, USA.

Omar Altalib

Department of Sociology University of Chicago Chicago, Illinois 